\title{
The origins and persistence of anadromy in brook charr
}

\author{
R. Allen Curry • Louis Bernatchez • \\ Fred Whoriskey Jr. • Céline Audet
}

Received: 25 September 2009/Accepted: 28 January 2010/Published online: 27 February 2010

(C) Springer Science+Business Media B.V. 2010

\begin{abstract}
We synthesized the results of a coordinated study examining the spatial and temporal movements, genetic structure, and physiological characteristics of sympatric populations of resident and sea-run brook charr across eastern Canada. Our goal was to critically evaluate three working hypotheses that may explain anadromous behaviour in brook charr: (1) resident and anadromous forms have different phylogenic origins; (2) anadromy emerges from freshwater residents; and (3) freshwater residency emerges from anadromous individuals. Our synthesis is consistent with the conclusion that freshwater residency emerging from anadromous individuals is most probable. Overall, anadromy in brook charr is poorly developed and the tactic of
\end{abstract}

R. A. Curry ( $\square)$

Canadian Rivers Institute, University of New Brunswick, Fredericton, NB E3B 5E1, Canada

e-mail: racurry@unb.ca

L. Bernatchez

Institut de Biologie Intégrative et des Systèmes (IBIS),

Université Laval, Quebec City, QC G1V 0A6, Canada

F. Whoriskey Jr.

Atlantic Salmon Federation, St. Andrew's,

NB E0G 2X0, Canada

C. Audet

Institut des Sciences de la mer de Rimouski, Université du Québec à Rimouski, Rimouski, QC G5L 3A1, Canada sea-running may be described as partial, facultative anadromy if the species must be described in terms of anadromy. The sea-run tactic most probably results from the species' propensity to move and disperse, the over-production of juveniles, an archetypical physiological ability to tolerate saline environments, and the persistence of critical habitats. When the spatial and temporal physical environments permit, the anadromous behaviour is expressed. The tactic creates an apparent fitness advantages related to growth, but it is not necessarily the only evolutionary stable strategy for a river. Most populations with searun forms are declining and successful conservation of sea-run forms will depend on managing harvests and more importantly, protection of the temporally and spatially complexity of critical habitats.

Keywords Anadromy · Strategy ·

Tactics · Salvelinus fontinalis $\cdot$ Salmonids ·

Critical habitats

\section{Introduction}

The brook charr, Salvelinus fontinalis, is considered a freshwater species and is found in almost all coldwater and reasonably pristine rivers and lakes of eastern North America from South Carolina, USA, to northern Québec, Canada (MacCrimmon et al. 
1971; Scott and Crossman 1973). Power (1980; Fig. 1) described the variability in the species' life history strategies and tactics. This plasticity of behaviour helps to explains its extensive distribution, which has also been developed and modified by postglacial access and re-colonization of the region (Legendre and Legendre 1984; Danzmann et al. 1998; Curry 2007), including the general warming of the climate in the past 10,000 years (e.g., Power 2002), physical barriers within drainages (e.g., Gowan et al. 1994), habitat requirements for spawning and incubation (e.g., Curry and Noakes 1995), and more recently anthropogenic stresses on habitats and populations (e.g., Ryther 1997).
Where the species has access to marine environments, it can adopt anadromous behaviour and such local populations are referred to as "sea-run" trout (Rounsefell 1957). There are many such extant populations from Maine to Labrador (e.g., Castric and Bernatchez 2003) and many more existed in the past (e.g., Ryther 1997), but to our knowledge, no allopatric, strictly anadromous $S$. fontinalis populations occur. When using the sea, they mostly confine themselves to their home river's estuary (Power 1980). Rounsefell (1957) and others (e.g., McCormick 1994) discuss anadromy as being poorly developed in brook charr. Arguments persist about the classification of anadromy as a strategy in fishes (Gross 1996;
Fig. 1 Variation in life history strategies and tactics for brook charr as described by Power (1980)

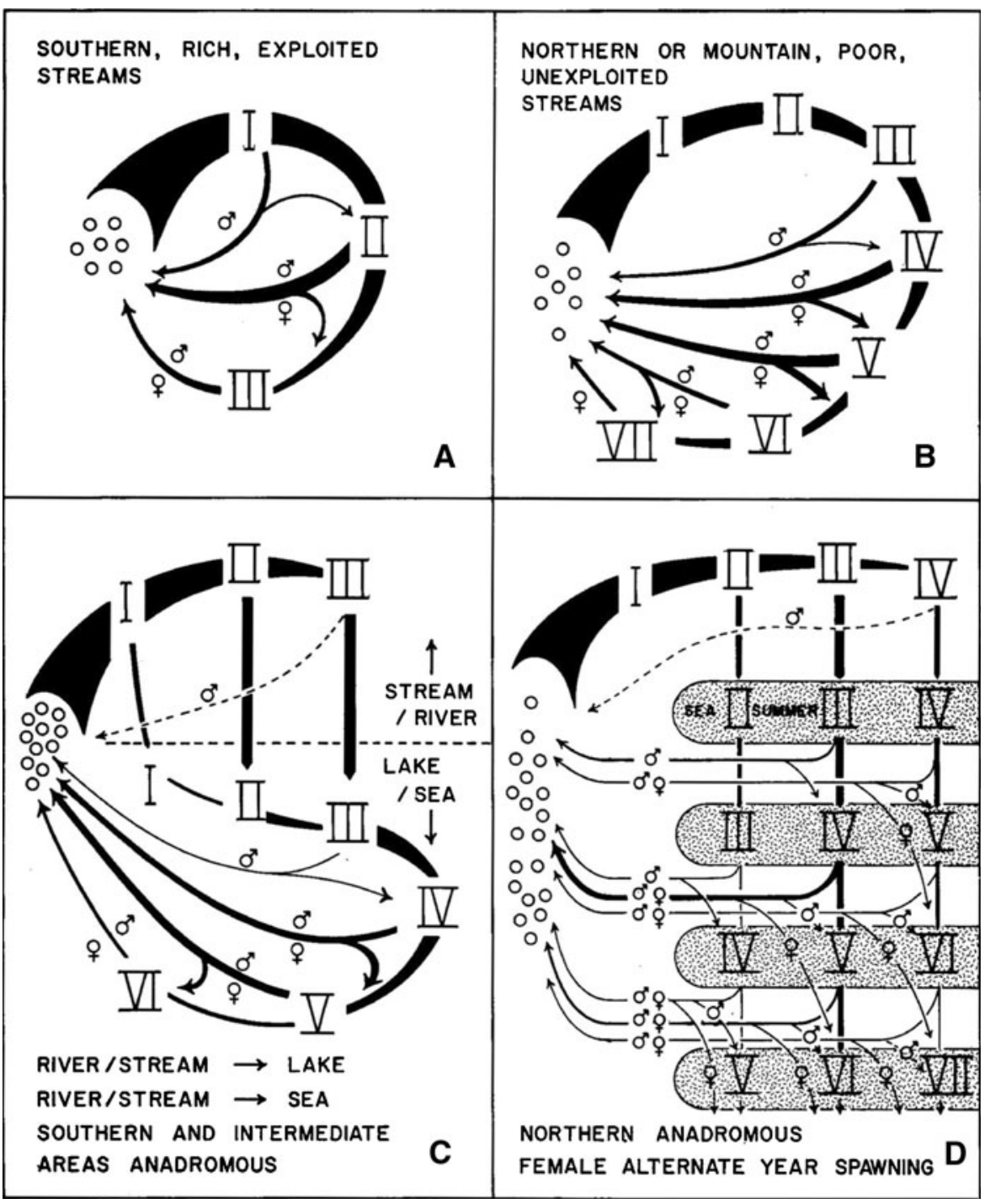


McDowall 2002; Hendry et al. 2004), and 'sea-run' may be better described as a suite of interrelated traits (Rounsefell 1957; Quinn and Myers 2004). Regardless, several species have sympatric freshwater resident and anadromous populations including brown trout Salmo trutta L. (Pettersson et al. 2001), cutthroat trout Oncorhynchus clarki (Trotter 1989), and rainbow trout Oncorhynchus mykiss (Walbaum) (Kline et al. 1990). Some species that would be described as anadromous can also adopt a strict, freshwater resident tactic, e.g., Atlantic salmon Salmo salar L. (Aubin-Horth and Dodson 2004) and sockeye salmon Oncorhynchus nerka (Walbaum) (Foote et al. 1989).

The facultative nature of moving from fresh water where reproduction must occur into marine environments and the variability among such tactics and strategies within many species raises questions about the evolutionary origins and significance of anadromy. These include what causes the anadromous behaviour to be expressed or repressed and what are the fitness consequences. Anadromous and resident forms may have different ancestral origins or vicarant history as observed in one population of brook charr and discussed by Fraser and Bernatchez (1995). Perhaps the anadromous strategy is resilient in residents (Olsen et al. 2006), i.e., it is genetically hardwired lying dormant for generations until some unknown mechanism triggers the behaviour (Thower et al. 2004). Alternatively, selective anadromy or partial migration (Jonsson and Jonsson 1993) may be a conditional reproductive strategy again genetically hardwired and triggered by an individual's condition such as body size (Thériault and Dodson 2003) or growth efficiency (Morinville and Rasmussen 2003).

Herein, we synthesize the results of a coordinated study that examined the spatial and temporal movements, genetic structure, and physiological characteristics of sympatric populations of resident and sea-run brook charr across eastern Canada. We discuss existing knowledge to critically evaluate three working hypotheses that may explain the origins and function (fitness) of anadromous behaviour in brook charr and related species: (1) resident and anadromous forms have different phylogenic origins, i.e., they are genetically separate groups in secondary contact; (2) anadromy emerges from founding populations of freshwater residents; and (3) freshwater residency emerges from founding populations of anadromous individuals.

\section{Methods}

Our studies span many populations of brook charr from Maine (USA) to Labrador (NF), but focused particularly on three rivers located along a $800 \mathrm{~km}$ north to south gradient: the Laval (\#40) River, Petite Cascapédia River (\#24), and Kennebecasis River (\#2: Fig. 2-Castric and Bernatchez 2003). The components of our study included: (1) documenting sea run movement patterns by radio and acoustic
Fig. 2 Location of brook charr populations discussed in detail (cross) and surveyed for DNA population structure across Maine and eastern Canada (filled circle) by Castric and Bernatchez (2003)

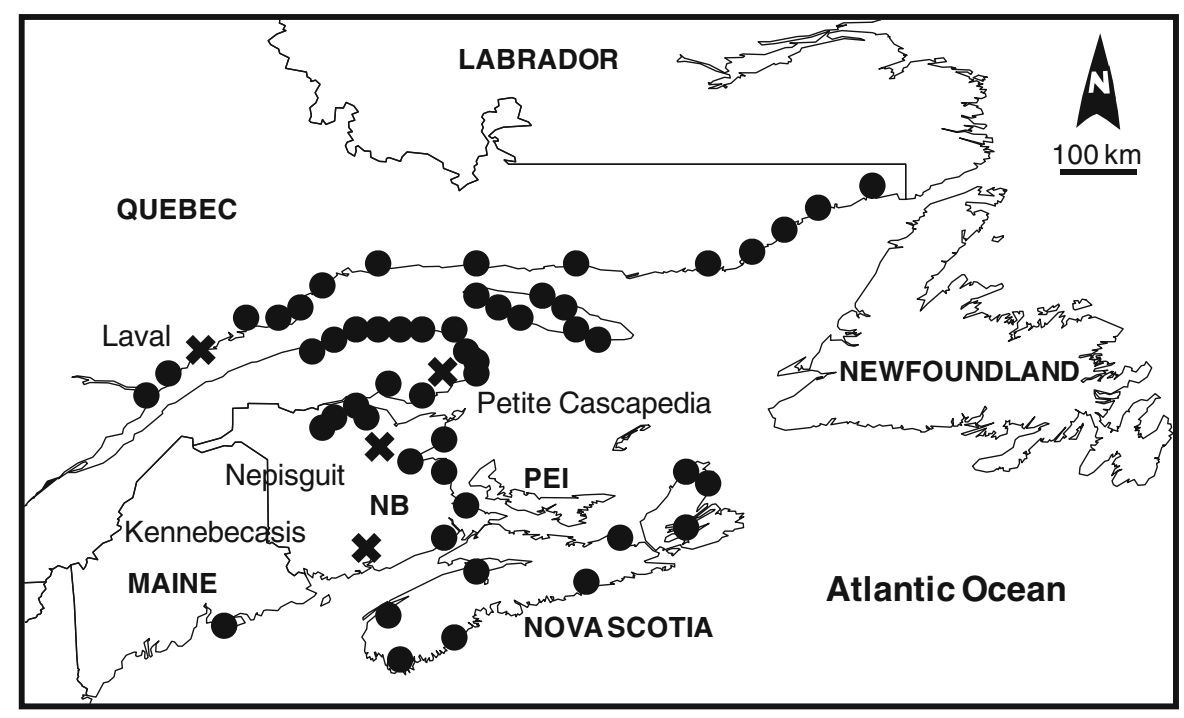


telemetry and trapping (Curry et al. 2002, 2006; van de Sande 2004), (2) measuring physiological and osomoregulatory status in the key rivers (Boula et al. 2002); and (3) examining DNA population structure to search for differentiation between sea run and fresh water resident forms (Castric and Bernatchez 2003, 2004; Perry et al. 2005).

Detailed descriptions of the principle rivers studied and analytical methods are available in the publications cited above. Here we have combined data from all studies and used it in multi-dimensional scaling plots (MDS-Primer 6) to gain new insights and test new hypotheses about movements to sea in the species. Additional data on brook charr from the Nepisiguit River above Grand Falls, northeastern New Brunswick (\#19, Fig. 2) was used for comparative purposes because this population is strictly freshwater resident (Hoggarth and Curry 1996).

\section{Results and discussion}

A synthesis of existing knowledge: patterns of movement

Brook charr express different life history tactics that lead to varied trajectories for growth and maturation across sizes and ages (e.g., Power 1980). For some populations this includes a group of individuals that moves to and resides in the marine environment. Our general knowledge of this group of fish indicates that they: (1) are immature juveniles and mature adults moving from fresh water to marine environments when ice cover is lost in the late winter or early spring (e.g., Castonguay et al. 1982; Montgomery et al. 1990); (2) rarely stray from home river estuaries (White 1941; Smith and Saunders 1958); (3) return to freshwater prior to spawning in early (Dutil and Power 1980) or late summer (Curry et al. 2006); (4) return early if they are mature females (Castonguay et al. 1982; Curry et al. 2006) due to ovulation dependency on a period of fresh water residence (Whoriskey et al. 1981; McCormick and Naiman 1985); (5) spawn in fresh and flowing water with some downstream movement post-spawning (Smith and Saunders 1958; Castonguay et al. 1982); and (6) can be iteroparious (Power 1980; Castonguay et al. 1982). Once a brook charr adopts the sea-run behaviour, they can repeat the migration between fresh and salt-water annually if they inhabit shorter river systems (Smith and Saunders 1958), although we don't know if all populations have repeat spawners and how many times the migration can occur. Individuals that spend time in estuaries grow significantly quicker and larger than similarly aged sympatric fresh water resident individuals (Dutil and Power 1980; Naiman et al. 1987).

Adding to and complicating interpretation of existing observations, the patterns of movement for larger ( $>20 \mathrm{~cm}$ fork length, FL) individuals, varied among the three rivers we studied in detail (Fig. 3). Laval River charr were the most "anadromous" because a group traveled to the estuary and remained at near full salinity (up to $27 \mathrm{ppt}$ and $10^{\circ} \mathrm{C}$ ) for the majority of the summer (Curry et al. 2006). Petite Cascapédia River charr entered the estuary and remained for a short period of a few weeks in spring (van de Sande 2004). The Kennebecasis River charr rarely entered the estuary and the saltwater environment (Curry et al. 2002).

Smaller, juvenile brook charr $(<20 \mathrm{~cm}$ FL) typically remain in fresh waters and the largest individuals can move downstream in late fall and early winter (Doyon et al. 1991; Curry et al. 2002). In early summer (June) in the Petite Cascapédia River, juveniles were readily captured in the estuary in full seawater, i.e., $26 \mathrm{ppt}$ and $10^{\circ} \mathrm{C}$ (http://www.mar.dfompo.gc.ca/science/ocean/gsl/gslmap.html; see also St. Laurent 2007). These age $1+$ juveniles are $13.9 \pm 1.5 \mathrm{~cm}$ FL (mean \pm 1 standard deviation), $26.7 \pm 9.9 \mathrm{~g}$ wet weight, and consumed marine plankton and benthic invertebrates $(n=45$; RAC,

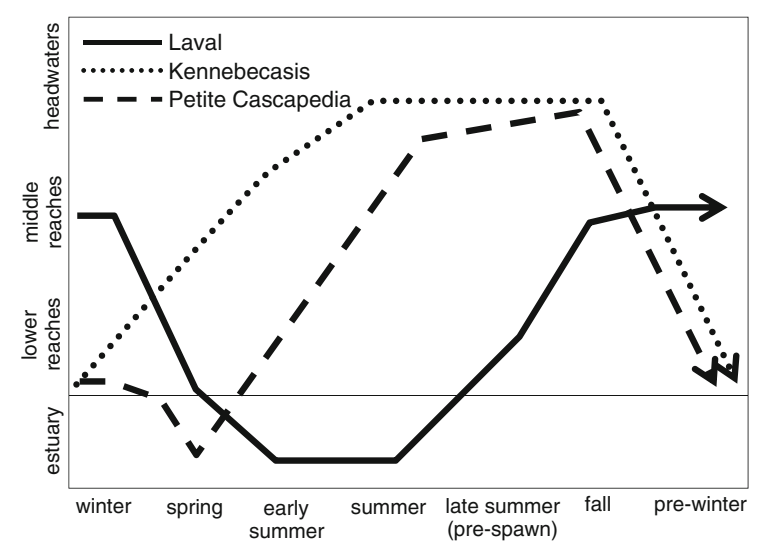

Fig. 3 Generalized seasonal and spatial movements of brook charr $>20 \mathrm{~cm}$ FL in the Kennebecasis, Petite Cascapédia, and Laval rivers of eastern Canada 
unpublished data). Lenormand et al. (2004) observed similar movements of age $1+$ and $2+$ with a few age $3+$ brook charr from the Sainte-Marguerite River, Saguenay River/Fjord, on the north shore of the St. Lawrence River, Québec, Canada. These charr had slower growth rates, e.g., size at age $1+$ was $\sim 9 \mathrm{~cm}$ $\mathrm{FL}$, and the estuary was $<18 \mathrm{ppt}$ with temperatures $\leq 15^{\circ} \mathrm{C}$. Laboratory studies suggested a minimum body size $\sim 18 \mathrm{~cm}$ is required to accommodate the physiological changes needed for osmoregulation in full salt water (Naiman et al. 1987; McCormick 1994). While acclimation and temperature of exposure will play an important role in determining where and when individuals can reside in an estuary (Claireaux and Audet 2000), there is again variability within this tactic for juvenile charr.

A synthesis of existing knowledge: patterns of growth

In rivers with sea-run individuals, there is a significant growth advantage reported for moving to and feeding in the marine environment (reviewed by Power 1980). We observed this in the Laval River where age $2+$ sea-run individuals were larger than age $3+$ river residents and the Petite Cascapédia River where sea-run individuals were larger at age $3+$ and 4+ (Fig. 4). However, going to sea is not always necessary to grow large: Kennebecasis River brook charr that remained in fresh water grew at the same rates (Fig. 4); the strictly, freshwater resident Nepisiguit River brook charr grew slower, but if they lived longer, they ultimately achieved the same maximum body size as observed for sea-run populations (Fig. 4); and, many strictly lacustrine populations grow large individuals (e.g., Quinn et al. 1994; Mucha 2005). We observed mature males and females among freshwater resident charr by age $1+$ in the Laval, Petite Cascapédia, and Kennebecasis populations. Some individuals aged $2+$ and $3+$ that went to sea were not mature in the Laval and Petite Cascapédia rivers. These larger, immature brook charr delayed their return to the river until late summer or fall (they are known locally as "jumping jacks"), but we don't know if they matured and spawned in subsequent years.

For brook charr and most fishes, large body size imparts a fitness advantage during a reproductive period, i.e., the largest individuals have the most and largest eggs, defend habitats best, and are preferentially selected as mates (Vladykov 1956; van den Berghe and Gross 1986; Blanchfield and Ridgway 1999; Thériault et al. 2007a). Many populations of brook charr have individuals that capitalize on marine resources to grow larger than their sympatric river residents, i.e., the estuary habitat appears to impart a growth advantage, but a large body size can be achieved in fresh waters (e.g., Fig. 4). The large, searun females in sympatric populations most probably produce more, larger eggs and potentially have more
Fig. 4 Size at age for male and female brook charr in the Laval (Lav), Petite Cascapédia (PC),

Kennebecasis (Ken) and Nepisiguit (Nep) rivers of eastern Canada. Laval and Petite Cascapédia are searun fish with size of river resident fish presented. Missing columns indicate no fish of that age class were captured

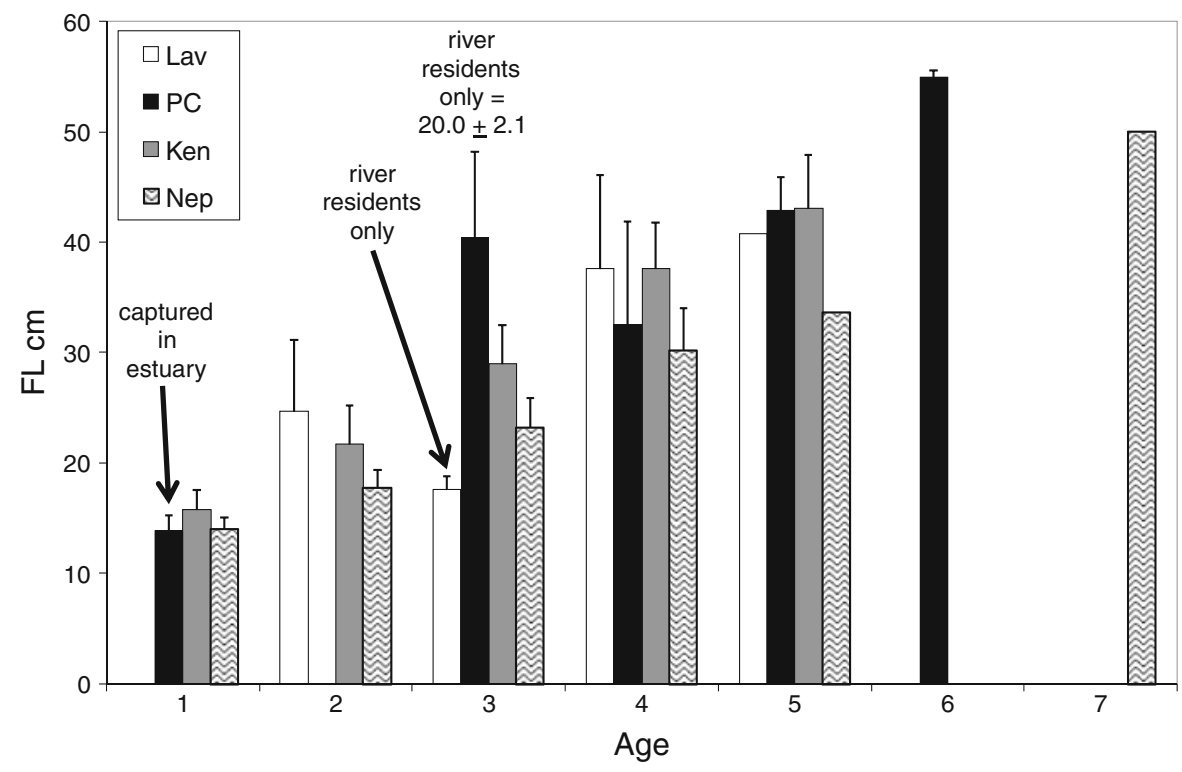


successful egg fertilizations within a spawning session; this remains to be investigated. Body size does not guarantee a fitness advantage because other environmental factors can impact reproductive success, e.g., limited habitat and superimposition of redds (e.g., Curry and Noakes 1995), regulation of embryo to free-swimming alevin survival (e.g., Curry et al. 1995), and most probably the evolution of size differences (e.g., Einum et al. 2002). Environments may also override maternal genetic control of embryo-alevin size (Perry et al. 2005). When newly emerged alevins from sea-run and resident females were reared in controlled laboratory conditions, the initially larger-bodied alevins of sea-run mothers retained their size advantage through their first summer (Chernoff and Curry 2007). We do not know if this initial size difference exists in the wild or persists beyond their first few months, although these individuals may be the larger migrants observed by Morinville and Rasmussen (2003, 2006).

Size can impart fitness advantages, but densitydependent factors such as intraspecific competition also influence fitness of newly emerged and juvenile salmonids (e.g., McLaughlin et al. 1999; Milner et al. 2003; Grant and Imre 2005). Where sea-run and residents spawn together, their respective contributions of free-swimming alevins, i.e., newly emerged youngof-the-year, does not appear to be dominated by searun offspring (Curry 2005; Jardine et al. 2008). The work of Morinville and Rasmussen (2006) suggests that less suitable habitats for brook charr, i.e., faster flows with greater energetic demands, are used by individuals that migrate to the sea. Whether and/or how this imparts a fitness advantage is unknown, e.g., do sea-run spawners influence the effective population size.

Convergence of understanding from movement patterns

The variability within and among the tactics related to the use of the marine environment follows some predictable patterns. Rather than a fixed anadromous strategy, the river specific, seasonal temperature and salinity regimes function to temporally and spatially delineate habitats for brook charr based on their physiological constraints and thus predicting the movement patterns among populations. Beginning post-spawning, moving downstream is common among populations (e.g., Smith and Saunders 1958; Castonguay et al. 1982) and downstream reaches generally provide deeper, lower velocity water during winter that minimize the energetic costs of holding station and stress from ice pack development and ice flows during spring break-up (Cunjak 1988, 1996; Power et al. 1993). In rivers where summer discharge is low, temperatures are extreme $\left(>20^{\circ} \mathrm{C}\right)$, and reproductive habitats are located long distances upstream in headwater areas $(>100 \mathrm{~km})$, individuals that are maturing in-season need to pass through the lower river in spring when water levels are high and temperatures are still cold in the spring, e.g., Kennebecasis River, and other New Brunswick rivers such as the Miramichi and Restigouche Rivers (personal communication, P. Cronin, NB Department of Natural Resources). Maturing migrants move close to headwater reaches by early summer where they inhabit deeper pools with overhead cover and discharging, cold groundwater, i.e., protected, coldwater habitats (Curry et al. 2002; van de Sande 2004). In the Laval River where summer water temperatures can be $>20^{\circ} \mathrm{C}$, maturing individuals entered fresh water in late summer (August), but traveled $<10 \mathrm{~km}$ at $2-10 \mathrm{~km} /$ day to deep, cool, groundwater-fed pools close to their reproductive habitats (Curry et al. 2006). Traversing these extreme temperatures appears to be a trade-off related to requirements of fresh water residency for maturity (Whoriskey et al. 1981; McCormick and Naiman 1985) and an extended estuary residence where growth is enhanced (Dutil and Power 1980; Naiman et al. 1987). If a river has an estuary that becomes warm $\left(>14^{\circ} \mathrm{C}\right)$ and saline $(>25 \mathrm{ppt})$ by early summer such as the Petite Cascapédia River, then brook charr are reentering fresh waters by late spring and thus minimizing osomoregulatory stress (van de Sande 2004). The Petite Cascapédia River conforms to the river-specific determination of movement patterns, but adds more yet unexplained complexity. Some post-spawn individuals from this river (4 of 20 tagged fish) move downstream and through $\sim 10 \mathrm{~km}$ of the Baie des Chaleur $\left(4-5^{\circ} \mathrm{C}\right.$ and $\left.28-30 \mathrm{ppt}\right)$ to the adjacent and much larger Grand Cascapédia River (Fig. 2) where they over-wintered and then returned in spring (van de Sande 2004; RAC, unpublished data). Some Petite Cascapédia River juveniles up to age $3+$ reside in a spatially complex estuary where salinity varied from 0 to 26 ppt (St. Laurent 2007; RAC, unpublished data and see also Smith and Saunders 1958). Overall, there 
were some characteristics of anadromy being expressed in each population, but it is the seasonal physical habitats of the river and physiology of the species that were the best predictors of the tactics used in each population as implied by Thériault et al. (2007b).

Working hypotheses for anadromous

behaviour in brook charr

While the environment of a river most probably controls the expression of anadromous-like behaviour in a population, what is it in the phylogeny of brook charr that provides the necessary genetic framework for the behaviour? There are three working, alternative hypotheses we propose to explain the expressed facultative, partial anadromy: (1) there are genetically unique, freshwater resident and anadromous forms arising from different lineages; (2) anadromous forms are repeatedly emerging from resident populations; and (3) resident forms are repeatedly emerging from anadromous forms. Each hypothesis offers a prediction we can test to some degree, i.e., strong genotypic separation of resident and anadromous individuals within systems for Hypothesis 1, all populations have freshwater resident ancestors with latent heritability for anadromous tactics in Hypothesis 2, and all populations are derived from anadromous ancestors with the latent heritability for becoming freshwater residents in Hypothesis 3.

For brook charr, the first hypothesis predicts secondary contact of freshwater and anadromous populations across eastern North America during the last 18,000 years of post-glacial dispersal. This requires repeated contact between freshwater-continental and marine-coastal populations as brook charr re-colonized the region as described by Legendre and Legendre (1984), Schmidt (1986), Danzmann et al. (1998), and Power (2002). Because sympatric sea-run and resident forms occur across this extensive area, secondary contact is predicted must have occurred repeatedly over this very large, spatial complex region. This would have had to occur over many centuries as ice receded and advanced, sea levels rose and fell, and waterways and rivers were created and destroyed. Curry (2007) demonstrated that brook charr from fresh water refugia could not enter and disperse across Maine, New Brunswick, Prince Edward Island, and Nova Scotia until about
8,000 years ago and their dispersal was restricted to a single freshwater pathway down the Saint John River. In addition, no fresh water populations survived the glaciations on the island of Newfoundland. Freshwater populations north of the St. Lawrence River re-colonizing from eastern Ontario and through Québec had even less potential for contact with searun populations given the timing of receding glaciers and topography (Legendre and Legendre 1984). There is just one location, central Québec's, Mistassini Lake, where a possible sea-run population from Hudson Bay and a resident, freshwater population appear to have come together in secondary contact (Fraser and Bernatchez 1995). Given our existing knowledge of the spatial and temporal complexity of the landscape during a relatively short, re-colonization period, it seems improbable that freshwater and sea-run forms repeatedly came in contact to produce the present-day, widespread occurrence of sea-run populations of brook charr.

If two forms experienced secondary contact, then a detectable genetic separation of forms is predicted (e.g., Bernatchez and Dodson 1991; Fraser and Bernatchez 1995). Most studies of many river systems have been unable to clearly separate sympatric freshwater residents from sea-run brook charr based on genetic analyses (Jones et al. 1997; Hébert et al. 2000; Castric and Bernatchez 2003; Rogers and Curry 2004; Perry et al. 2005). Boula et al. (2002) working with Laval River brook charr reported the greatest genotypic separation of forms, but the samples were from the main river and a potentially parapatric population from a tributary, Adams Brook, e.g., more recent, divergent selection pressure in the river (Thériault et al. 2007b). We revisited our microsatellite data for the Laval, Petite Cascapédia, and Kennebecasis rivers (see methods described by Boula et al. 2002 and Castric and Bernatchez 2003) to improve our resolution of analysis by adding where possible, classifications of freshwater resident or migratory individuals based on their behaviour from our biotelemetry studies. A migratory behavior was assigned if the individual went to sea and if they didn't, then they were classified as river residents. Large individuals ( $>20 \mathrm{~cm}$ FL) that were captured in the estuary or moving downstream in spring and within a few kilometers of the estuary were classified as migratory. Additional river residents were sampled from targeted upstream areas not accessible to large, 
potentially sea-run charr. These classifications have some uncertainty because we still don't fully understand why and when an individual may adopt the searun behaviour, i.e., the observed non-migratory individuals could become sea-run later in life and individuals in headwaters may similarly move down past barriers to become sea-run later in their life (e.g., Pettersson et al. 2001).

There was no clear microsatellite-based separation of resident and migratory individuals within or among rivers in our studies (Fig. 5). There are distinct, within river groupings which have been reported for other populations of brook charr (Rogers and Curry 2004; Curry 2005); however, the grouping in the three rivers were not explained by movement patterns, i.e., travelling upstream, downstream, or by season. Without clear and consistent genotypic separation of sympatric resident and sea-run forms and given the complex history of re-colonization of the region, we conclude that Hypothesis 1-freshwater resident and anadromous forms are divergent forms in secondary contact, and Hypothesis 2-anadromous forms are emerging repeatedly from freshwater resident populations, are insufficient by themselves to explain the evidence in-hand.

This leads to the third hypothesis—-straying, searun brook trout created present-day sympatric populations where resident forms subsequently arose and anadromous behaviour has continued to be expressed by some individuals. Power et al. (1973) and Rogers and Curry (2004) proposed such a hypothesis for coastal rivers and Thower et al. (2004) imply the same resilient, genetic disposition to migrate to the sea in rainbow trout. One prediction from this hypothesis is an intermediate state of genotypic separation between forms within a river which is what we observed and has been repeatedly reported for the brook charr and close relatives (e.g., Hindar et al. 1991; Jones et al. 1997; Hébert et al. 2000). In addition, accessibility to the large expanse of eastern North American coastal areas would have been possible for recolonization. This would have occurred during the period of glacial retreat when an abundance of fresh and brackish water existed along the receding ice margins, throughout the areas of today's headwater areas, and before sea levels receded (Hughes et al. 1985; Power 2002; Curry 2007). Such physical connectivity in less salty waters with a cold climate would have provided the environmental conditions for relatively free movement along

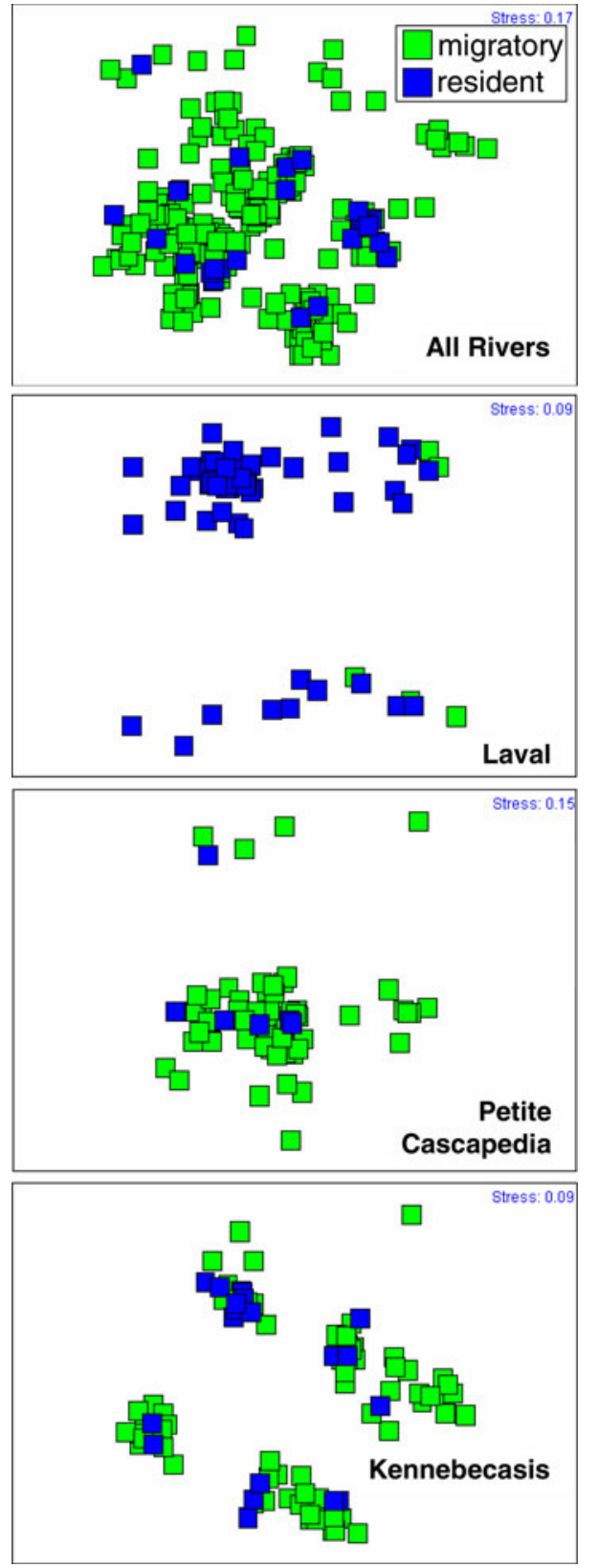

Fig. 5 Multidimensional scaling plots (MDS) plots based on six microsatellite DNA markers for migratory and resident brook charr in the Kennebecasis, Petite Cascapédia, and Laval rivers of eastern Canada

the coast and facilitated a colonization from south and east (e.g., Schmidt 1986) into new rivers as they developed. The genetic structure of present-day populations across the region corroborates this prediction (Castric and Bernatchez 2003). Similarly, as sea levels receded and present-day watersheds with lakes and 
rivers were created, it is also probable that many allopatric, resident populations of brook charr were created as water bodies were isolated. Hypotheses 3 provides the most probable explanation for the occurrence of brook charr across their historic range and for the resiliency of anadromous behaviour (Thériault et al. 2007b; Thower et al. 2004) that could persist or be expressed when river environments were appropriate.

We are not discounting secondary contact of searun and freshwater resident brook charr or the development of anadromous behaviours in populations that could have originated from strictly freshwater sources, i.e., those recolonizing along freshwater routes from central North America (Curry 2007). Rather, it seems most probable that most extant brook trout populations with sea-run forms originated initially from sea-run individuals re-colonizing along the evolving coast lines of eastern North America during the last 18,000 years (Hypothesis 3).

The persistence of sea-running brook charr

The physical environment is continuously evolving, mostly at the slow, geologic time scale of change but also much quicker when humans modify systems. The general consensus among resource managers is that sea-run brook charr populations are declining (e.g., Ryther 1997). Most management agencies have set goals for protecting or creating new or reestablishing sea-run populations. For new populations with sea-running forms to be created naturally, individuals will either need to stray along the coast from their home river estuary to a river that can support the anadromous behaviour, and/or a river's environmental conditions need to evolve to create habitats and their spatial and temporal linkages to support the anadromous behaviour. The present rate of straying appears low (e.g., White 1941; Curry et al. 2006), few sea-run populations persist south of the Bay of Fundy (Ryther 1997), and southern populations are more genetically isolated than northern populations (Castric and Bernatchez 2003). This indicates environmental conditions, most probably the general warming of the climate and associated changes in habitats (Meisner 1990) and humaninduced, fractionated river habitats (Ryther 1997) no longer favour dispersal among rivers in the south. It also seems likely that creation of new sea-run populations from allopatric, resident populations will be rare. Rivers of the south have been and continue to decrease in size (discharge) and become warmer (e.g., Juanes et al. 2004; Monk and Curry 2009). While individuals may go to sea in some populations and there is some evidence of this in Maine (M. Gallagher, Maine Department of Inland Fisheries), the persistent environmental changes in southern rivers are significant challenges for sustaining anadromous behaviours now and into the future. In the far north, e.g., Labrador, we presume most populations are stable with respect to allopatry or sympatry because these rivers have had relatively stable environments over the last 8,000 years (Prowse et al. 2006). Straying among rivers most probably persists in the north and with continued global warming, there may be new opportunities to create new or expand populations with sea-running forms.

A generalized dispersal tactic appears to be fixed in juvenile brook charr. This is probably triggered by some combination of ontogenic development and the changes in physiology and behavior (McLaughlin 2001) possibly related to variable energetic costs incurred in different river habitats (Morinville and Rasmussen 2003; Thériault and Dodson 2003) and density-dependent factors (Hendry et al. 2004; Grant and Imre 2005). Consequently, there may always be some freshwater resident individuals in rivers that find their way to the sea even in southern rivers where the likelihood of establishing sea-run populations is low. Existing knowledge best supports a hypothesis that habitat and specifically, density of individuals at different life history stages controls dispersal in salmonids and therefore is a principle mechanism that generates sea-run individuals in a population. For salmonid juveniles, reducing intra-specific interactions by reducing densities enhances survival (Grant and Imre 2005; Elliott and Elliott 2006), can reduce downstream emigration (Keeley 2001), and decrease abundance of anadromous individuals (Thorpe 1993; Morita et al. 2005). Inter-specific competition involving juveniles may also influence emigration and favour migration to the sea (Morinville and Rasmussen 2006). These mechanisms act on juveniles in the smaller habitats of low order streams where they were spawned. While certain stressors are alleviated by dispersal, emigration to larger habitats of higher order, main stem reaches in rivers increases other potential threats from the larger physical environment 
(e.g., flow and ice), from predators, and from competition with larger (older) individuals and more species. We know that some juveniles have mass and rapid movements towards the sea (Castonguay et al. 1982; Lenormand et al. 2004), but we are still working to understand the mechanisms and consequences of emigration for brook charr juveniles.

Individuals that travel to the sea will grow large and therefore require larger scale habitats within the river when they return. Large individuals need "large spaces", i.e., water of sufficient depth and protective cover with appropriate temperature regimes that are season-specific, e.g., providing spatial connectivity to traverse the river to summer and winter holding areas, spawning areas. Summer habitat are the deepest pools with cold water inputs and cover (e.g., deep water, fallen trees, overhanging banks or vegetation); winter habitats are relatively warm water and deep enough to protect large individuals from ice accumulations, e.g., a lake for some individuals (Curry et al. 2002, 2006). Spawning and incubation habitats similarly need to accommodate large individuals, deeper water and sometimes larger substrate materials. For brook charr, these habitats are often provided by discharging groundwater (e.g., Curry et al. 1995) which can be spatially limited and density-dependent, intra-specific competition among spawners based on body size can exist (Curry and Noakes 1995; Blanchfield et al. 2003). Physical space to hold, move, and reproduce is a common factor that appears to limit the occurrence and persistence of large, sea-run individuals and thus, the habitats we have described to date including their temporal connectivity can be defined as critical (Fausch et al. 2002; Rosenfeld and Hatfield 2006). If space is critical among life history periods, then density must also be a significant mechanism driving the creation and persistence of sea-run individuals in populations.

Managers of brook charr populations with sea-run individuals are concerned about declining numbers of large-bodied individuals, presumed to be sea-run fish, across the species range (Ryther 1997). This trend is consistent with the model of Thériault et al. (2008) that predicted harvesting of anadromous individuals would result in a higher tendency for residency and smaller bodied individuals within a population. Our results indicate that habitat protection is perhaps the most significant action required to sustain existing populations. Stocking of fish is a popular management tool, but it will be ineffectual for these brook charr populations if habitats of any life history stage are already at capacity in terms of numbers and biomass, i.e., the density control mechanism. Artificial introductions of freshwater resident brook charr into estuaries have enhanced growth of individuals that used the marine environment and returned to fresh waters (Gibson and Whoriskey 1980; Whoriskey et al. 1981). Stocked juveniles found their way from estuaries to upstream, summer habitats in the Miramichi River, NB (M. Hambrook, Miramichi Salmon Conservation Centre, South Esk, NB); however, there is no evidence that stocking in any manner can introduce, sustain, or enhance sea-run forms in a population, and this is most probably linked to limitations of critical habitats. There are most probably other factors that are or have the potential to reduce survivability, e.g., climate warming across their range and the resultant loss of temperature dependent habitats (e.g., Monk and Curry 2009). Whatever the mechanism, fewer individuals translates to a smaller effective population size. Curry's (2005) and Jardine et al. (2008) observation of variable and unexpected low reproductive contributions of sea-run females to some populations may reflect the threat of low numbers of this form in these populations. Ultimately, the loss of sea-run forms translates to a continuing threat to the aquatic biodiversity of the region (http://www.eman-rese.ca/ eman/reports/publications/rt_biostrat) where the fish species richness is already depauperate as a consequence of the last glaciations (e.g., Curry 2007).

\section{Conclusions}

Anadromy in brook charr has been described as poorly developed (McCormick 1994). Figure 6 summarizes our conclusions regarding the expression of anadromous behaviour in brook charr, and the characteristics of that behaviour as it related to the river-specific conditions we observed. We are proposing that a river's environment dictates how the behaviour will be expressed and thus the patterns we have described are not the only patterns expected among populations, e.g., the shorter rivers of Prince Edward Island (Smith and Saunders 1958). The tactic of sea-running in brook charr populations would be better described as having some elements of anadromy (Rounsefell 1957), e.g., 


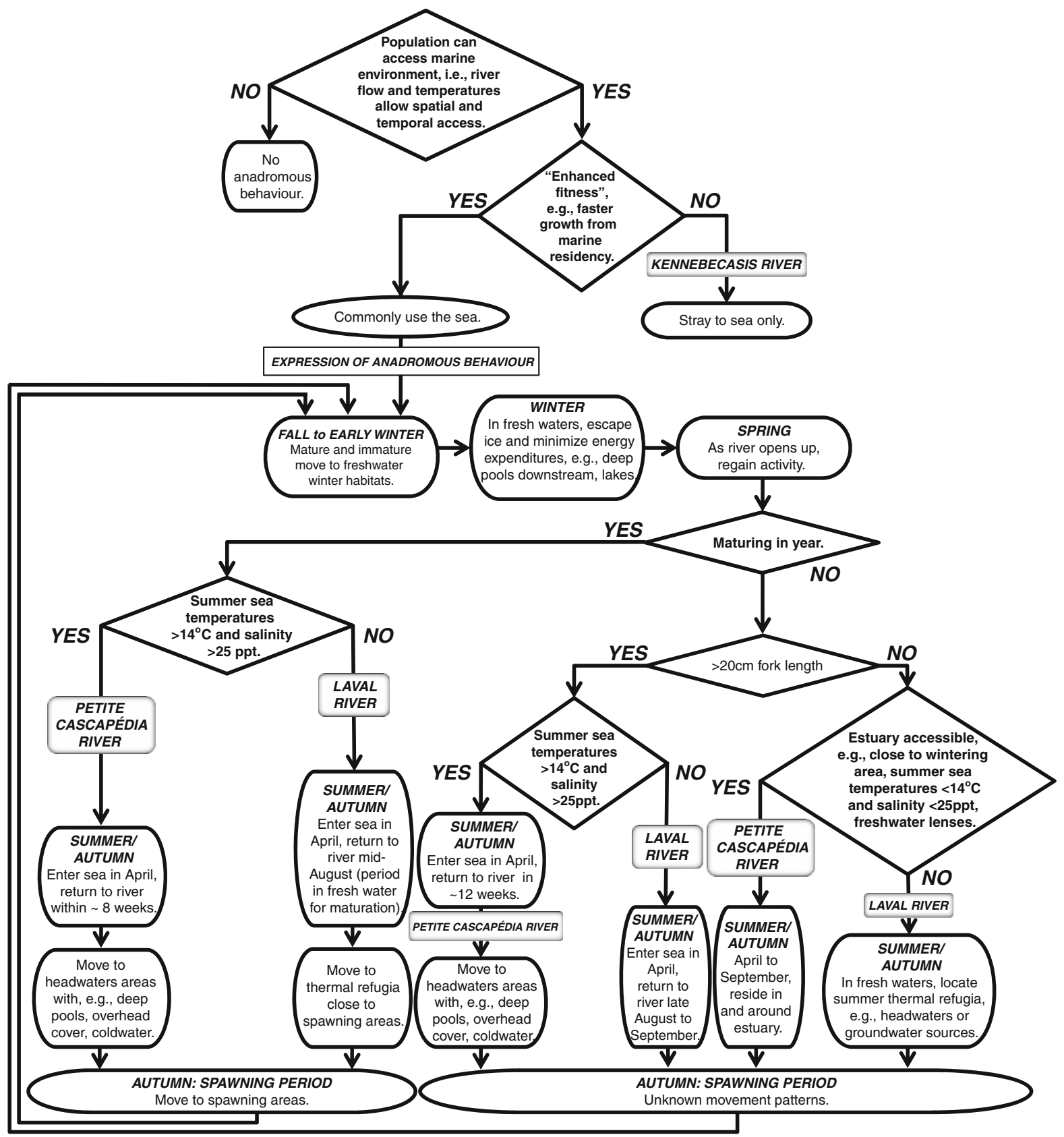

Fig. 6 Characterization of the environmental conditions required for brook charr to express anadromous behaviour (top) and the river-specific behaviours observed in three rivers of eastern Canada

the species exhibits partial, facultative anadromy (if the species must be described in terms of anadromy). The sea-run tactic observed in present day populations most probably results from the species' propensity to move and disperse, over-production of juveniles, a residual (archetypical) physiological ability to tolerate saline environments, and the persistence of critical habitats. When river environments permit, anadromous behaviour is expressed. Although the tactic can create apparent fitness advantages related to growth, it is probably never the only evolutionary stable strategy for this species. Our findings and discussion strongly point to the protection of the described critical habitats including their temporal connectivity as a prerequisite 
for the successful conservation of sea-run forms within populations of brook charr. In addition, habitats limit production of embryos, juveniles, and large adults; consequently, management activities that increase abundance at these life history stages, e.g., stocking of fish, will most probably have limited success because of the limited available habitat. As sea-run forms disappear, the region's limited biodiversity suffers as does one of the region's socio-culturally important recreational fisheries.

Finally, our observations and conclusions are the culmination of significant effort by our teams and many others working with sea-run brook charr and species with similar behaviours, e.g., Arctic charr and brown, rainbow, and cutthroat trout. It is important to understand that we are still working with and presenting hypotheses and future research will need to test the arising predictions.

Acknowledgments We thank the many graduate students and their assistants who conducted the bulk of the field and laboratory work for our studies, especially D. Boula, V. Castric, D. Courtemanche, J. van de Sande, and M. Gautreau. Many organizations and funding agencies supported the research including the Québec-Ministère des Ressources naturelles et de la Faune, New Brunswick Department of Natural Resources, New Brunswick Environmental Trust Fund, Camp Brûlé, Zec Petite Cascapédia, ZEC Forestville, and Sussex Fish and Game Association. This project was funded in part by an NSERC Strategic Grant, 201893-97.

\section{References}

Aubin-Horth N, Dodson JJ (2004) Influence of individual body size and variable thresholds on the incidence of a sneaker male reproductive tactic in Atlantic salmon. Evolution 58:136-144

Bernatchez L, Dodson JJ (1991) Phylogeographic structure in mitochondrial DNA of the lake whitefish (Coregonus clupeaformis) and its relationship to Pleistocene glaciations. Evolution 45:1016-1035

Bernatchez L, Wilson CC (1998) Comparative phylogeography of nearctic and palearctic freshwater fishes. Mol Ecol 7:431-452

Blanchfield PJ, Ridgway MS (1999) The cost of peripheral males in a brook trout mating system. Anim Behav 57:537-544

Blanchfield PJ, Ridgway MS, Wilson CC (2003) Breeding success of male brook trout (Salvelinus fontinalis) in the wild. Mol Ecol 12:2417-2428

Boula D, Castric V, Bernatchez L, Audet C (2002) Anadromy in brook charr (Salvelinus fontinalis): physiological, endocrine and genetic bases. Environ Biol Fishes 64:229-242

Castonguay M, Fitzgerald GJ, Coté Y (1982) Life history and movements of anadromous brook charr (Salvelinus fontinalis) in the St-Jean River, Gaspé, Quebec. Can J Zool 60:3084-3091

Castric V, Bernatchez L (2003) The rise and fall of isolation by distance in the anadromous brook charr (Salvelinus fontinalis Mitchill). Genetics 163:983-996

Chernoff E, Curry RA (2007) First summer growth predetermined in anadromous and resident brook charr. J Fish Biol 70:334-346

Claireaux G, Audet C (2000) Seasonal changes in the hypoosmoregulatory ability of brook charr: the role of environmental factors. J Fish Biol 56:347-373

Cunjak RA (1988) Physiological consequences of overwintering in streams: the cost of acclimatization. Can J Fish Aquat Sci 45:443-452

Cunjak RA (1996) Winter habitat of selected stream fishes and potential impacts from land-use activity. Can J Fish Aquat Sci 53(Suppl. 1):267-282

Curry RA (2005) Assessing the reproductive contributions of sympatric anadromous and freshwater-resident brook trout. J Fish Biol 66:741-757

Curry RA (2007) Late glacial impacts on dispersal and colonization of Atlantic Canada and Maine by freshwater fishes. Q Res 67:225-233

Curry RA, Noakes DLG (1995) Groundwater and spawning site selection by brook charr (Salvelinus fontinalis). Can J Fish Aquat Sci 52:1733-1740

Curry RA, Noakes DLG, Morgan GE (1995) Groundwater and incubation habitats, embryo survival, and alevin emergence of brook charr (Salvelinus fontinalis). Can J Fish Aquat Sci 52:1741-1749

Curry RA, Sparks D, van de Sande J (2002) Movement patterns of a riverine population of brook trout. Trans Am Fish Soc 131:551-560

Curry RA, van de Sande J, Whoriskey FW Jr (2006) Temporal and spatial habitats of anadromous brook charr in the Laval River and its estuary. Environ Biol Fish 76: 361-370

Danzmann RG, Morgan RP, Jones MW, Bernatchez L (1998) A major sextet of mitochondrial DNA phylogenetic assemblages extant in eastern North American brook charr (Salvelinus fontinalis): distribution and post-glacial dispersal patterns. Can J Zool 76:1300-1318

Doyon JF, Hudon C, Morin R, Whoriskey FG Jr (1991) A court terme des movements anadromes saisonniers pour une population d'omble de fontaine (Salvelinus fontinalis) du Nouveau Québec. Can J Fish Aquat Sci 48:2212-2222

Dutil JD, Power G (1980) Coastal populations of brook trout (Salvelinus fontinalis) in Lac Guillaume-Delisle (Richmond Gulf) Quebec. Can J Zool 58:1828-1835

Einum S, Hendry AP, Fleming IA (2002) Egg size evolution in aquatic environments: does oxygen availability constrain size? Proc R Soc Lond B 269:2325-2330

Elliott JM, Elliott JA (2006) A 35-year study of stockrecruitment relationships in a small population of sea trout: assumptions, implications and limitations for predicting targets. In: Harris G, Milner N (eds) Sea trout: biology, conservation management. Blackwell, Oxford, pp 257-278

Fausch KD, Torgersen CE, Baxter CV, Li HW (2002) Landscapes to riverscapes: bridging the gap between research and conservation of stream fishes. Bioscience 52:483-498 
Foote CJ, Wood CW, Withler RE (1989) Biochemical genetic comparison of sockeye salmon and kokanee, the anadromous and nonanadromous forms of Oncorhynchus nerka. Can J Fish Aquat Sci 46:149-158

Fraser DJ, Bernatchez L (1995) Allopatric origins of sympatric brook charr populations: colonization history and admixture. Mol Ecol 14:1497-1509

Gibson RJ, Whoriskey FC Jr (1980) An experiment to induce anadromy in wild brook trout in a Quebec river on the north shore of the Gulf of St. Lawrence. Nat Can 107:101-110

Gowan C, Young MK, Fausch KD, Riley SC (1994) Restricted movement in resident stream salmonids: a paradigm lost? Can J Fish Aquat Sci 51:2626-2637

Grant JWA, Imre I (2005) Patterns of density-dependent growth in juvenile stream-dwelling salmonids. J Fish Biol 67:100-110

Gross MR (1996) Alternative reproductive strategies and tactics: diversity within sexes. Tree 11:92-98

Hébert C, Danzman RG, Jones MW, Bernatchez L (2000) Hydrography and population genetic structure in brook charr (Salvelinus fontinalis, Mitchill) from eastern Canada. Mol Ecol 9:971-982

Hendry AP, Bohlin T, Jonsson B, Berg OK (2004) To sea or not to sea: anadromy versus non-anadromy in salmonids. In: Hendry AP, Stearns SC (eds) Evolution illuminated: salmon and their relatives. Oxford University Press, New York, pp 92-125

Hindar K, Jonsson B, Ryman N, Ståhl G (1991) Genetic relationships among landlocked, resident, and anadromous brown trout, Salmo trutta L. Heredity 66:83-91

Hoggarth CT, Curry RA (1996) The Nepisiguit river brook trout study. New Brunswick Cooperative Fish and Wildlife Research Unit, Fisheries Report \#96-1

Hughes T, Borns Jr HW, Fastook JL, Hyland MR, Kite JS, Lowell TV (1985) Models of glacial reconstruction and deglaciation applied to Maritime Canada and New England. Geol Soc Am, Special Paper 197, pp 139-150

Jardine TD, Chernoff E, Curry RA (2008) Maternal transfer of carbon and nitrogen to progeny of sea-run and resident brook trout (Salvelinus fontinalis). Can J Fish Aquat Sci 65:2201-2210

Jones MW, Danzmann RG, Clay D (1997) Genetic relationships among populations of wild resident, and wild hatchery anadromous Brook Char. J Fish Biol 50:29-40

Jonsson B, Jonsson N (1993) Partial migration: niche shift versus sexual maturation in fishes. Rev Fish Biol Fish 3:348-365

Juanes F, Gephard S, Beland KF (2004) Long-term changes in migration timing of adult Atlantic salmon (Salmo salar) at the southern edge of the species distribution. Can J Fish Aquat Sci 61:2392-2400

Keeley ER (2001) Demographic responses to food and space competition by juvenile steelhead trout. Ecology 82:12471259

Kline TC Jr, Goering JJ, Mathisen OA, Poe PH, Parker PL (1990) Recycling of elements transported upstream by runs of Pacific Salmon: $\delta^{15} \mathrm{~N}$ and $\delta^{13} \mathrm{C}$ evidence in Sashin Creek, southeastern Alaska. Can J Fish Aquat Sci 47:136144
Legendre P, Legendre V (1984) Postglacial dispersal of freshwater fishes in the Quebec peninsula. Can J Fish Aquat Sci 41:1781-1802

Lenormand S, Dodson JJ, Ménard A (2004) Seasonal and ontogenetic patterns in the migration of anadromous brook charr (Salvelinus fontinalis). Can J Fish Aquat Sci 61:65-67

MacCrimmon HR, Gotts BL, Campbell JS (1971) World distribution of brook trout, Salvelinus fontinalis: further observation. J Fish Res Board Can 28:452-456

McCormick SD (1994) Ontogeny and evolution of salinity tolerance in anadromous salmonids: hormones and heterochrony. Estuaries 17:26-33

McCormick SD, Naiman RJ (1985) Hypoosmoregulation in an anadromous teleost: influence of sex and maturation. $\mathrm{J}$ Exp Zool 234:193-198

McDowall RM (2002) The origin of the salmonid fishes: marine, freshwater... or neither? Rev Fish Biol Fish 11:171-1792

McLaughlin RL (2001) Behavioural diversification in brook charr: adaptive responses to local conditions. J Anim Ecol 70:325-337

McLaughlin RL, Ferguson MM, Noakes DLG (1999) Adaptive peaks and alternative foraging tactics in brook charr: evidence of short-term divergent selection for sitting-andwaiting and actively searching. Behav Ecol Sociobiol 45:386-395

Meisner JD (1990) Effect of climatic warming on the southern margins of the native range of brook trout, Salvelinus fontinalis. Can J Fish Aquat Sci 47:1065-1070

Milner NJ, Elliott JM, Armstrong JD, Gardiner R, Welton JS, Ladle M (2003) The natural control of salmon and trout populations in streams. Fish Res 62:111-125

Monk WA, Curry RA (2009) Ecological significance of spatial and temporal variability in stream temperatures across north-eastern North America. Challenges for diadromous fishes in a dynamic global environment. Am Fish Soc Symp 69:215-230

Montgomery WL, McCormick SD, Naiman RJ, Whoriskey FG Jr, Black G (1990) Anadromous behavior of brook charr (Salvelinus fontinalis) in the Moisie River, Quebec. Pol Arch Hydriobiol 37:43-61

Morinville GR, Rasmussen JB (2003) Early juvenile bioenergetic differences between anadromous and resident brook trout (Salvelinus fontinalis). Can J Fish Aquat Sci 60:401410

Morinville GR, Rasmussen JB (2006) Does life-history variability in salmonids affect habitat use by juveniles? A comparison among streams open and closed to anadromy. J Anim Ecol 75:693-704

Morita K, Arai T, Kishi D, Tsuboi J (2005) Small anadromous Salvelinus malma at the southern limits of its distribution. J Fish Biol 66:1187-1192

Mucha JM (2005) Habitat use, movement patterns, and home ranges of coaster brook trout in Nipigon Bay, Lake Superior. Unpublished MSc Thesis, Lakehead University, Thunder Bay

Naiman RJ, McCormick SD, Montgomery WL, Morin R (1987) Anadromous brook charr, Salvelinus fontinalis: opportunities and constraints for population enhancement. Mar Fish Rev 49:1-13 
Olsen J, Wuttig K, Fleming D, Kretschmer E, Wenburg J (2006) Evidence of partial anadromy and resident-form dispersal bias on a fine scale in populations of $\mathrm{On}$ corhynchus mykiss. Conserv Genet 7:613-619

Perry GML, Audet C, Bernatchez L (2005) Maternal genetic effects on adaptive divergence between anadromous and resident brook charr during early life history. J Evol Biol 18:1348-1361

Pettersson JC, Hansen MM, Bohlin T (2001) Does dispersal from landlocked trout explain the coexistence of resident and migratory trout females in a small stream? J Fish Biol 58:487-495

Power G (1980) The brook charr, Salvelinus fontinalis. In: Balon EK (ed) Charrs: salmonid fishes of the Genus Salvelinus. Dr. W. Junk, The Hague, pp 141-203

Power G (2002) Charrs, glaciations, and season ice. Environ Biol Fish 64:17-35

Power G, Pope GF, Coad BW (1973) Postglacial colonization of the Matamek River, Quebec, by fishes. J Fish Res Board Can 30:1586-1589

Power G, Cunjak RA, Flannagan J, Katopodis C (1993) Biological effects of river ice. In: Prowse TD, Gridley NC (eds) Environmental aspects of river ice. National Hydrology Research Institute, Science Report 5, pp 97125

Prowse TD, Wrona FJ, Reist JD, Gibson JJ, Hobbie JE, Lévesque LMJ, Vincent WF (2006) Historical changes in Arctic freshwater ecosystems. Ambio 35:339-345

Quinn TP, Myers KW (2004) Anadromy and the marine migrations of Pacific salmon and trout: Rounsefell revisited. Rev Fish Biol Fish 14:421-442

Quinn NMW, Korver RM, Hicks FJ, Monroe BP, Hawkins RR (1994) An empirical model of lentic brook trout. N Am J Fish Manag 14:692-709

Rogers SM, Curry RA (2004) Genetic population structure of brook trout inhabiting a large river watershed. Trans Am Fish Soc 113:1138-1149

Rosenfeld JS, Hatfield T (2006) Information needs for assessing critical habitat of freshwater fish. Can J Fish Aquat Sci 63:683-698

Rounsefell G (1957) Anadromy in North American salmonidae. Fish Bull US Fish Wildl Serv 131:171-185

Ryther JH (1997) Anadromous brook trout: biology, status and enhancement. Trout Unlimited, Inc, Virginia

Schmidt RE (1986) Zoogeography of the northern Appalachians. In: Hocutt CH, Wiley EO (eds) The zoogeography of North American freshwater fishes. Wiley, New York, pp 137-159
Scott WB, Crossman EJ (1973) Freshwater fishes of Canada. Bulletin 184. Fisheries Research Board of Canada, Ottawa

Smith RL, Saunders JW (1958) Movements of the brook trout, Salvelinus fontinalis (Mitchill), between and within fresh and salt water. J Fish Res Board Can 15:1403-1449

St. Laurent J (2007) Caractérisation de la population anadrome d'omble de fontaine estivant dans l'estuaire de la Rivière Petite Cascapédia. Unpublished MSc thesis, L'Université du Québec á Rimouski, Rimouski

Thériault V, Dodson JJ (2003) Body size and the adoption of a migratory tactic in brook charr. J Fish Biol 63:1144-1156

Thériault V, Bernatchez L, Dodson JJ (2007a) Mating system and individual reproductive success of sympatric anadromous and resident brook charr, Salvelinus fontinalis, under natural conditions. Behav Ecol Sociobiol 62:51-65

Thériault V, Garant D, Bernatchez L, Dodson JJ (2007b) Heritability of life-history tactics and genetic correlation with body size in a natural population of brook charr (Salvelinus fontinalis). J Evol Biol 20:2266-2277

Thériault V, Dunlop ES, Dieckmann U, Bernatchez L, Dodson JJ (2008) The impact of fishing-induced mortality on the evolution of alternative life-history tactics in brook charr. Evol Appl 1:409-423

Thorpe JE (1993) Impacts of fishing on genetic structure of salmonid populations. In: Cloud JG, Thorgaard GH (eds) Genetic conservation of salmonid fishes. Plenum, New York, pp 67-80

Thower FP, Hard JJ, Joyce JE (2004) Genetic architecture of growth and early life-history transitions in anadromous and derived freshwater populations of steelhead. J Fish Biol 65(Supplement A):286-307

Trotter PC (1989) Coastal cutthroat trout: a life history compendium. Trans Am Fish Soc 118:463-473

van de Sande J (2004) Seasonal movement patterns and habitat use of anadromous brook charr in freshwater, estuarine and marine environments. Unpublished MSc thesis, University of New Brunswick, Fredericton

van den Berghe EP, Gross MR (1986) Length of breeding life of coho salmon (Oncorhynchus kisutch). Can J Zool 64:1482-1486

Vladykov VD (1956) Fecundity of wild speckled trout (Salvelinus fontinalis) in Quebec Lakes. J Fish Res Board Can 13:799-841

White HC (1941) Migrating behavior of sea-running Salvelinus fontinalis. J Fish Res Board Can 5:258-264

Whoriskey FG Jr, Naiman RJ, Montgomery WL (1981) Experimental sea ranching of brook trout (Salvelinus fontinalis, Mitchill). J Fish Biol 19:637-651 